\title{
仮想輝度分布法による実大空間の明るさ感推定に関する検討 VALIDITY OF ESTIMATING ENVIRONMENTAL BRIGHTNESS OF REAL-SIZE SPACE BY THE VIRTUAL LUMINANCE DISTRIBUTION METHOD
}

\author{
荻 内 康 雄*, 石田 泰一郎** \\ Yasuo OGIUCHI and Taïchiro ISHIDA
}

\begin{abstract}
In our former study, we proposed Virtual Luminance Distribution Method (VLD Method), a method for estimation of environmental brightness based on perceptual determinants of environmental brightness, and showed that VLD Method is valid for environmental brightness estimation of a model-space. In this paper we performed an experiment using real-size experimental booth. In the experiment, subjects evaluated environmental brightness for various lighting conditions of the booth. Our analysis indicates that:

1. The estimated environmental brightness by the VLD method has rather high correlation with the psychophysically evaluated environmental brightness.
\end{abstract}

2. The VLD Method estimates the effect of local lighting on environmental brightness with a fair degree of precision.

\author{
Keywords: Environmental brightness, Real-size space, Psychophysical evaluation, Luminance distribution, Virtual Luminance \\ Distribution Method, Local lighting \\ 空間の明るさ感, 実大空間, 心理評価, 輝度分布, 仮想輝度分布法, 局部照明
}

\section{1. 序論}

近年の地球温暖化問題を背景として, 建築照明分野でも省エネル ギーが改めて意識されるようになり, 光源については発光効率のよ いLED の開発や昼光の利用が注目されている.一方, 建築照明設計 においても，視作業に必要な機能を満たすだけでなく，光環境の快 適性やエネルギー効率に対する配慮が今日的な課題となっている.

ところで，一般の建築照明設計では，建物種別ごとの基準照度を 満たすことにその主眼が置かれ, 設計指標として水平面照度が重視 されている. 元来, 基準照度はある想定される視作業の遂行を確保 するためのものであり, 光の快適性や心理効果をそれだけで記述す ることはできない.

機能的で快適な照明環境を実現するためには，基準照度を満たす だけではなく, 光環境に対する人間の感覚を適切に評価することが 必要になる. そこで最も重要な感覚の一つは, 空間全体の明るさに 対する印象，すなわち空間の明るさ感であろう，照明の機能と快適 性, さらに省エネルギーなどの観点から照明設計における空間の明 るさ感評価の重要性が指摘されている ${ }^{122}$. 著者らは空間の明るさ感 の定量的な評価法として仮想輝度分布法と名付けた方法を考案し， 模型空間を用いた心理実験によってその有効性を検証してきた ${ }^{3)-7)}$. 本研究は実大スケールの空間に対する仮想輝度分布法による明るさ 感推定の有効性を検討することを目的としている，まず，以下では
空間の明るさ感についての既往研究を概観し，仮想輝度分布法開発 の経緯とその概要について説明する。

\section{2. 空間の明るさ感に関する既往研究}

これまでの多くの研究により, 空間の明るさ感は, 光環境のさま ざまな要因の影響を受けることが指摘されており，ある特定の位置 で測定された照度や輝度などの単一の測光量との一般的な対応関係 は見出されていない 10)-13).これまでの研究によって報告された空間 の明るさ感に影響する要素をまとめると，以下のようになる。

(1) 光源の種類

高演色型のランプが室内の明るさ感增加させる効果があることが 多くの研究によって示されている ${ }^{14)-17}$. これらの結果に基づき, 各 種の高演色型蛍光灯ではその明るさ感の向上がうたわれている.

(2) 視野内の光源 (高輝度部分) の有無

Bernecker ら ${ }^{18}$ は光源が視野に入るかどうかが明るさ感に影響する ことを示している. Akashi ら ${ }^{19)}$ は光源の輝きが明るさ感を增大させ る効果があることを明らかにし，オフィスのアンビエント照明に輝 き発光部を組み込むことで, 省エネルギーと快適性の両立を実現し ている ${ }^{20)}$.

(3) 輝度分布

Loe ( $^{21)}$ は水平面を中心とした上下 $40^{\circ}$ 視野の平均輝度が明るさ 感と相関を持つことを示している. また, Tiller ら ${ }^{22)}$ はオフィスを
* 京都大学大学院工学研究科建築学専攻 研修員 $\cdot$ 工博

** 京都大学大学院工学研究科建築学専攻 助教授. 工博
Research Fellow, Dept. of Architecture and Architectural Engineering, Kyoto Univ., Dr. Eng.

Assoc. Prof., Dept. of Architecture and Architectural Engineering, Kyoto Univ., Dr. Eng. 
想定した実際の部屋において，輝度の非一様性が空間をより明るく 見せるという結果を報告している. Shepherd は薄暗さの研究 ${ }^{23)}$ 24)に おいて，非一様な輝度分布が薄暗さに影響を与えるとしている，小 林ら ${ }^{25)}$ も粗い輝度変化は不均一な照明をイメージさせ, 明るさ感を

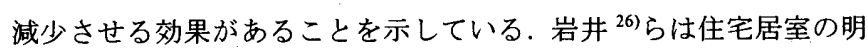
るさ感に関する研究において, 壁面の平均輝度および隅角部の輝度 が明るさ感への寄与が高いことを示している，さらに，この結果に 基づき実際の住宅空間において明るさ感向上をめざした照明器具が

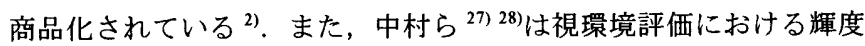
分布の重要性を指摘しており，輝度分布測定とフィルタリングを組 み合わせることで，シーンの明るさ感を推定する方法を提案してい る $^{29)}$.

(4) 室内の内装

池田ら ${ }^{30)}$ があざやかな有彩色の物体を室内に取り入れることによ って，その空間の明るさ感が増すことを明らかにしている.

このように空間の明るさ感に影響する物理的な特徵は多岐にわ たって検討されている.しかし，これらの研究の多くでは，ある物 理要素と空間の明るさ感との相関関係が明らかにされているものの, 明るさ感が導かれる心理過程（因果関係）は必ずしも明らかではな い。このため，ある物理量と空間の明るさ感の相関関係が成立する ための条件が明確でなく，それらの物理量をただちに一般的な評価 モデルとして採用することは困難である．

一方, 池田らは照明認識視空間という概念を提唱して空間の明る さ感を含む照明空間に対する人間の認識の解明を進めており ${ }^{30-34)}$, 照明認識視空間のサイズという心理量の測定によって実環境におけ る空間の明るさ感評価を試みている ${ }^{34)}$. しかし, 工学的な観点から, 照明認識視空間のサイズを実際の空間の物理量に基づいて定量化し， 空間の明るさ感推定法に結びつけるための研究は行われていない.

筆者らは, 以上の背景の下に, 空間の明るさ感に基づく設計を実 現するためには，まず空間の明るさ感を決定付けている光環境の主 要な物理的特徴を明らかにし，それに基づいて空間の明るさ感を推 定する工学的な方法を開発することが必要であると考えた．次に筆 者らのこれまでの研究の概要を記す。

\section{3. 仮想輝度分布法による明るさ感推定}

空間の明るさ感は, 光環境の何らかの物理的特徵を捉えた感覚に 基づいて決定されると考えられる. したがって, 空閒の明るさ感を 定量的に推定するためには, 空間の明るさ感に対応する感覚量を見 出し，その感覚量を光環境の物理量を用いて近似的に記述できれば よいことになる

そこで，まず初めに，われわれは空間の明るさ感を決定する感覚 量について検討するための実験を行った，まず，建築空間に存在す る物理的な光の成分を大別することに着目し, 空間を直接照射する 光と内面で反射して空間内に拡散している光の二つの成分に分けて 考えた，実験ではこの二つの光の成分に対する認識が独立に成立す るかどうか，またそれぞれの認識量が空間の明るさ感とどのように 関係するのか調べた.すなわち, 実験で観察者が評価した感覚量は, 空間を照明する光源の強さに対する感覚（光源の強さ感）と，壁面 など表面間の相互反射により空間を満たしている光の量に対する感
覚（空間の光量感）であり，これらの感覚と空間の明るさ感を評価 する実験を行った ${ }^{3)-6)}$ 。赛験の結果, 空間の明るさ感評価值は, 空 間の光量感評価值との相関関係が強いこと,および光源の強さ感評 価値との相関関係は弱いことが示された.

この実験結果は, 空間の明るさ感老決めている主要な感覚量は空 間の光量感であることを意味していると考えられる，すなわち空間 の明るさ感推定のためには空間の半量感に対応する指標を光環境の 物理量から算出すればよいということがいえる．ここで，人間の視 覚に対する主要な入力情報は輝度分布であることを考えると, 空間 の明るさ感推定のベースとなる物理量として空間の輝度分布を採用 することが適当であると考えられる，すなわち，次の問題は室空間 の輝度分布データから，その空間に満ちていると人が感じる光の量 をどのようにして算出するかということである，例えば，照明配光 や内装反射率がほぼ一様な場合は，輝度の平均值を用いれば，目的 とする量を近似的に表現できそうである，ただし，より一般的な状 況で空間の光量感を評価するためには，スポット光による高輝度領 域や低反射率表面による低輝度領域などの局所的な輝度変化は，全 体の輝度変化から排除して考えなくてはならない：なぜならば，そ れらはあくまでも局所的な光の変化と認識されるため, 空間全体を 占めると認識される光の量, すなわち空間の光量感に与える影響は 小さいからである．ところで，このような局所的な光の成分と全体 に渡る光の成分を自動的に分離することは图難である，そこで，著 者らは逆のアプローチを考え，まず初めに，評価対象の空間全体に 光が満ちている状態を想定し，その㳊によこて作り出される輝度分 布（仮想輝度分布）の形状を, 空間の明るさ感推定の基準として用 いる方法を提案した。つまり，実测 れれた輝度分布から仮想輝度分 布の形状に沿う成分を抽出することによって，空間全体に渡る光の 量を推定することが可能になるのである。このように仮想輝度分布 を用いて実測輝度分布から空間の明るさ感を推定する新たな工学的 手法を仮想輝度分布法と呼び，その有効性を検討してきた ${ }^{7-9)}$.

ここで仮想輝度分布法の概要を説明する．仮想輝度分布法では， まず試験対象となる空間全体に分布する光による輝度分布を計算に よって求め，その仮想的な輝度分布(以下，「仮想輝度分布」と呼ぶ) のパターンをあらかじめ準備する.ここで空間全体に分布する光と は天井面全体が拡散光源であると設定した場合の光の分布を仮定し ている、次いで, 仮想輝度分布を実測された輝度分布に最適近似す ることによって，実測輝度分布から仮想輝度分布に沿う成分を求め る.このとき局所的な輝度変化成分は排除されることになる.

具体的な明るさ感推定にあたっては, 天井面が均等拡散光源かつ すべての面が均等拡散反射面であり壁面反射率, 室の形状は評価対 象となる空間と同一であるような仮想的な空間(以下，「仮想空間」 と呼ぶ)に形成される輝度分布を仮想輝度分布とした。この場合， 仮想輝度分布のパラメータは仮想的な光源(以下,「仮想光源」と呼 ぶ)の輝度 $L$ のみとなり，この仮想光源の輝度 $L$ から試験対象空間の 明るさ感推定值を算出することが可能となる.

実測された輝度分布から対応する仮想光源の輝度を算出する手 続きは以下のようなものである.

まず，仮想光源の輝度を 1 としたときの仮想輝度分布(単位仮想 輝度分布) $L v$ を算出する。

続いて各測定点 $i$ について, 


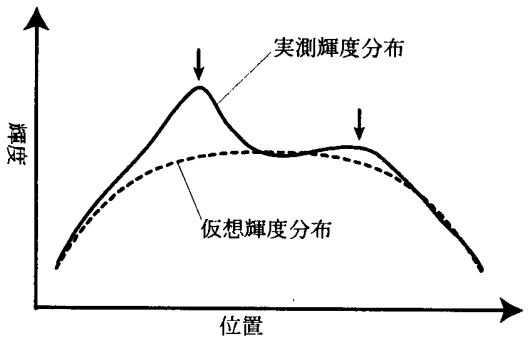

図 1 仮想輝度分布法における実測輝度 分布と仮想輝度分布の関係

$$
L_{i}=\frac{L_{r i}}{L_{v i}}
$$

によって対応する仮想光源輝度 $L_{i}$ をもとめる.ただし， $L_{r i}$ は測定点 $i$ の実測輝度， $L_{v i}$ は $i$ に対応する点の仮想輝度である.

実際の輝度分布の形状と仮想輝度分布とは異なるため, $L_{i}$ は $i$ に よって異なる值をとる．そこで，このような $L_{i}$ の集合の下側 5 パー センタイル值を空間の光量感を表わす指標，すなわち空間の明るさ 感指標とする.

奏測輝度分布と仮想輝度分布の模式図を図 1 に示す. 図 1 中の矢 印で示している仮想輝度分布から外れた部分は局所的な光として認 識され，空間の明るさ感への寄与は小さいと考えられる。なお，図 1 では 1 次元の輝度分布での例を示しているが，実際の明るさ感評 価值の算出では 2 次元の輝度分布で計算している.

仮想輝度分布法による明るさ感推定について検討するために, 模 型空間を使用して行った実験 》では, 被験者の与えた明るさ感評価 值と, 仮想輝度分布法による明るさ感推定值との間の相関は高かっ たのに対して, 被験者の目の位置での鉛直面照度や視野内の平均輝 度など他の明るさ感指標との相関は低かった。この結果から, 仮想 輝度分布法による明るさ感推定は模型空間に対して適用可能である こと，また他の手法よりも良好に明るさ感推定が行えることが示さ れた。

しかし，この明るさ感評価実験は，あくまで模型内の空間を外か ら見て評価するというものであり，そのサイズなどは現実の空間と は大きく異なる．また，実際に観察者が実大空間の中に入って感じ る空間の明るさ感が, 模型空間を外から観察した場合と同様な要因 によって導かれるものであるのかどうかは明らかにされていない．

\section{4. 実大空間での明るさ感評価実験}

\section{1 実験目的}

仮想輝度分布法による明るさ感推定が害大空間に対して適用可 能かどうかについては，実大ス施ーレの空間を用いた実験によって 改めて検証する必要がある，そこで，本実験では仮想輝度分布法に よる明るさ感推定の実大空間への適用可能性を検証することを目的 として，実際の建築空間を想定した実大実験ブースでの明るさ感評 価実験を行った。

\section{2 実験概要}

実験では被験者は一般住宅の居室を想定した実大ブース内の明 るさ感を評価した．明るさ感の評価にはマグニチュード推定法を採 用した。

データ解析では, 仮想輝度分布法により推定した明るさ感評価値 (以下，「明るさ感推定值」と呼ぶ)と実験で被験者が与えた明るさ感 評価值(以下,「明るさ感評価值」と呼ぶ)とを比較することにより， 仮想輝度分布法が実大空間の明るさ感推定に適用可能かどうかを検 討した.

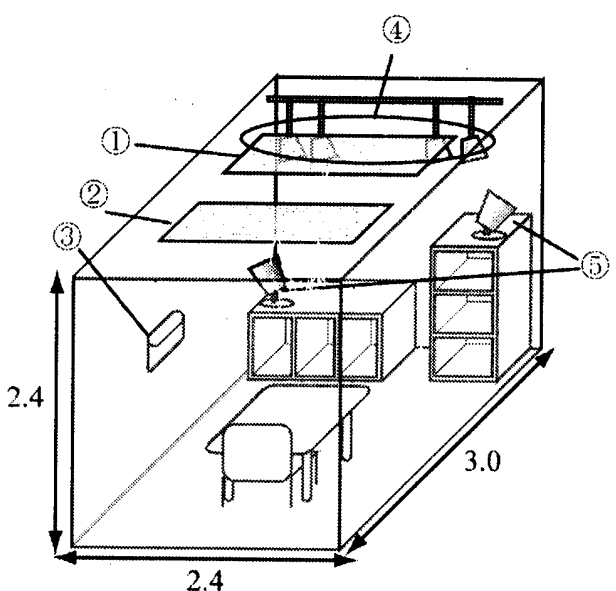

図 2 実験ブースの概要. (1)〜(5)は照明器具を表わし，(1)：天 井照明 F，(2)：天井照明 B，(3)：壁面照明，(4)：スポットラ イトA、(5): スポットライトB. 図中の長さの単位は $\mathrm{m}$

表 1 実験ブースの内装. カッコ内は反射率

\begin{tabular}{|l|l|}
\hline 天井 & クロス貼り (0.89) \\
\hline 壁 & 壁紙 $(0.84)$ \\
\hline 床 & カーペット $(0.70)$ \\
\hline
\end{tabular}

表 2 照明器具の詳細. 設置場所の番号は図 2 中の番号に対応している

\begin{tabular}{|c|c|c|c|c|c|}
\hline 設置場所 & 名称 & 台数 & メーカー/型番 & 使用している電球 & 取り付计位置など \\
\hline (3) & 壁面ライト & 1 & $\begin{array}{r}\text { 松下電工 } \\
\text { NL32352WK } \\
\end{array}$ & 100V 40Wコンパクト蛍光灯 (電球色) & 左側壁面 \\
\hline (4) & スポットライトA & 4 & $\begin{array}{r}\text { 松下電工 } \\
\text { NLW310-R8J }\end{array}$ & 12V 50Wハロゲンランプ & $\begin{array}{l}\text { 天井から吊り下げ. } \\
\text { 正面壁方向 } 45^{\circ} \text { 下向き }\end{array}$ \\
\hline (5) & スポットライトB & 2 & $\begin{array}{l}\text { 東京メタル工業 } \\
\text { (品番不明) }\end{array}$ & 100V 75Wハロゲンランプ & $\begin{array}{l}\text { 本棚と壁面に1つずつ固定. } \\
\text { 正面壁方向 } 60^{\circ} \text { 上向き }\end{array}$ \\
\hline
\end{tabular}


表 3 天井照明の出力強度比 (単位[\%])

\begin{tabular}{|c|c|c|}
\hline & 天井照明 $\mathrm{F}$ & 天井照明 $\mathrm{B}$ \\
\hline 中 & 100 & 100 \\
\hline 強 & 331 & 116 \\
\hline 弱 & 87 & 60 \\
\hline
\end{tabular}

\section{3 実験装置}

実験ブースの概要を図 2 に, 条件の詳細を表 1 に示す. 実験ブー ス内には一般住宅の居室を想定して，本棚，テーブルなどを配置し た.

ブースには大きく分けてブース全体を照明する全体照明と,ブー スの壁面の一部を照明する局部照明が設置された，全体照明は天井 直付け型ベースライト 2 台である。 また，局部照明は壁面照明，ス ポットライト A, スポットライト B の 3 系統である. 照明器具の詳 細を表 2 に示す.

2 台の全体照明はそれぞれ独立に,「高」、「中」，「低」，「消灯」 の 4 段階調光が可能である. 天井照明の出力強度の条件を表 3 に示 す.

また, 3 系統の局部照明は系統ごとに独立に点滅可能である、な お, 天井照明の調光状態および局部照明の点滅は実験者が手元のス イッチで切り替える.

被験者は実験ブース内の椅子に座り, 自然な姿勢で自由に室内を 観察することができる，ただし，順応状態の極端な変動を避けるた め, 照明器具を長時間直視することは禁止した.

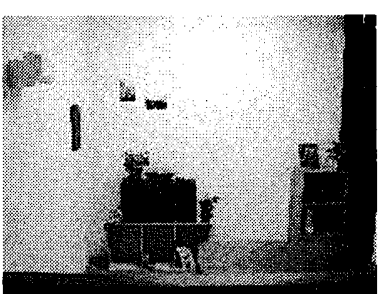

(1) 照明条件 1

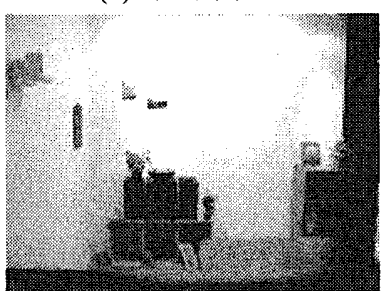

(3) 照明条件3

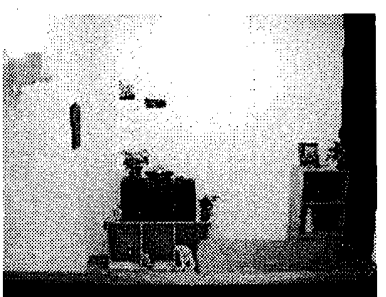

(2) 照明条件 2

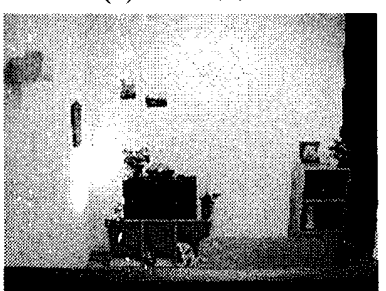

(4) 照明条件 4
写真1 照明条件1〜4 (天井照明F系列)の時の実験ブー ス内部の様子。撮影位置は被験者位置後方.

\section{4 実験条件}

2 台の天井照明を「中」で点炈し、室内全体をほぼ均等に照明し た条件を明るさ感評価の基準となる「基準条件うとした．

空間の明るさ感評価の対象となるテスト条件は, 天井照明 2 台の 調光と局部照明 3 系統の点滅の組合せによる 18 通りである: テスト 条件は天井照明のみ，あるいは天井照明と局部照明 1 系統の組合せ からなる「天井照明 $\mathrm{F}$ 系列」(条件 1４), 「天井照明 B 系列」(条件

表 4 実験で使用された照明条件

\begin{tabular}{|c|c|c|c|c|c|c|c|c|c|c|}
\hline & \multirow{2}{*}{ 系列 } & \multicolumn{2}{|c|}{ 天井 } & \multirow{2}{*}{ 壁面 } & \multirow{2}{*}{$\begin{array}{c}\text { スポット } \\
\mathrm{A}\end{array}$} & \multirow{2}{*}{$\begin{array}{c}\text { スポット } \\
\text { B }\end{array}$} & \multirow{2}{*}{$\begin{array}{c}\text { 水平面 } \\
\text { 照度 [lx] }\end{array}$} & \multirow{2}{*}{$\begin{array}{c}\text { 鉛直面 } \\
\text { 照度 [lx] }\end{array}$} & \multirow{2}{*}{$\begin{array}{l}\text { 明るさ感 } \\
\text { 推定值 [-] }\end{array}$} & \multirow{2}{*}{ 輝度分布などの概略 } \\
\hline & & $\mathrm{F}$ & B & & & & & & & \\
\hline 基淮 & & 中 & 中 & & & & 300 & 198 & . & 水平面照度がほぼ均一な照明 \\
\hline 1 & \multirow{4}{*}{$\begin{array}{l}\text { 天井照明 } \\
\text { F系列 }\end{array}$} & 強 & & & & & 444 & 360 & 115 & 正面壁全体が高輝度 \\
\hline 2 & & 強 & & On & & & 560 & 453 & 115 & 左側壁の輝度が滈い \\
\hline 3 & & 強 & & & On & & 502 & 450 & 122 & 正面壁中央付近の輝度が高い \\
\hline 4 & & 強 & & & & On & 484 & 407 & 117 & 隅角部の耀度が高い \\
\hline 5 & \multirow{4}{*}{$\begin{array}{l}\text { 天井照明 } \\
\text { B系列 }\end{array}$} & & 強 & & & & 192 & 75.1 & 56.9 & 左右の壁の被験者に近い部分が高輝度 \\
\hline 6 & & & 強 & On & & & 311 & 169 & 64.4 & 条件 2 と類似 \\
\hline 7 & & & 強 & & On & & 269 & 164 & 88.5 & 条体3と類似 \\
\hline 8 & & & 強 & & & On & 234 & 122 & 73.6 & 条件4 と類似 \\
\hline 9 & \multirow{4}{*}{$\begin{array}{l}\text { 天井照明 } \\
\text { F\&B采列 }\end{array}$} & 弱 & 弱 & & & & 215 & 156 & 85.0 & 水平面照成さ 泀ほ均一だが，暗い \\
\hline 10 & & 弱 & 弱 & On & & & 338 & 252 & 91.9 & 条件2と類似 \\
\hline 11 & & 弱 & 弱 & & On & & 288 & 241 & 99.8 & 条件3と類似 \\
\hline 12 & & 弱 & 弱 & & & On & 254 & 201 & 91.8 & 条件 4 と類似 \\
\hline 13 & & 弱 & & On & On & & 363 & 320 & 103 & 左側壁と正面中央付近の耀度が高い \\
\hline 14 & & 弱 & I & On & & On & $329^{\circ}$ & 279 & 94.8 & 左側壁と隅角部の輝度が高い \\
\hline 15 & & 弱. & & & On & On & 281 & 270 & 93.2 & 正面壁中央付近と隅角部の輝度が高い \\
\hline 16 & & & 弱 & On & On & & 237 & 198 & 79.9 & 条件13 と類似 \\
\hline 17 & & & 弱 & On & & On & 203 & 158 & 73.9 & 条件 14 と類似 \\
\hline 18 & & & 弱 & & On & On & 153 & 148 & 83.6 & 条件 15 と類似 \\
\hline
\end{tabular}

注) 照明器具の略称恃次の通り壁面：壁面ライト,スポット：スポットライト 
表 5 輝度分布測定時の撮影条件

\begin{tabular}{|l|l|}
\hline 焦点距離 & $38 \mathrm{~mm}$ \\
\hline 絞り & $\mathrm{F} 5.6$ \\
\hline シャッター速度 & $1 / 15 \sim 1 / 200$ \\
\hline 画像サイズ & $1024 \times 768$ \\
\hline 画像形式 & 非圧縮 TIFF \\
\hline 色深度 & 8 ビット白黒 \\
\hline
\end{tabular}

表 6 単位仮想輝度分布計算の諸条件

\begin{tabular}{|l|l|}
\hline サイズ (幅 $\times$ 奥行×高さ)* & $2.4 \times 3.0 \times 2.4$ \\
\hline 内部反射率 (天井面, 壁面, 床面)* & $0.89,0.84,0.70$ \\
\hline 表面反射性状 & 完全拡散反射 \\
\hline パッチ分割 & 各面 $10 \times 10=100$ (計 600) \\
\hline 光源 & 天井面が完全拡散面光源 \\
\hline 光源輝度 & $1 \mathrm{~cd} / \mathrm{m} 2$ \\
\hline サンプリング点/実測輝度測定点 & 正面壁と左右壁の分割パッチ中央点 (計 300 点) \\
\hline 照明計算 & ラジオシティ法 \\
\hline
\end{tabular}

*実験ブースと同一の条件
5 8), 「天井照明 F\&B 系列」(条件 9 12)の 3 つの系列と, 天井照 明と局部照明 2 系統を組み合わせた 6 条件(条件 13〜18)からなる. 基準条件を含む各照明条件における照明の組合せを表 4 に示す．ま た例として条件 1〜4 における室内の様子を写真 1 に示す.

分析のベースとなる測光量として, 各照明条件について被験者の前 のテーブル(高さ $70 \mathrm{~cm}$ )中央での水平面照度, 被験者の目の位置(高さ $120 \mathrm{~cm})$ での鉛直面照度，および被験者の目の位置からの室内の輝度 分布を測定した. 水平面照度と鉛直面照度の測定には照度計(ミノル タ T-10)を用いた。 また，輝度分布は Moore らの研究 ${ }^{35)}$ を参考にデ ジタルカメラ(オリンパス C3040)で撮影した画像から算出した。画 像の撮影条件は表 5 に示すとおりである。

各条件における水平面照度, 鉛直面照度の測定結果を表 2 に示す.

\section{5 実験手順}

実験を始める前に被験者は基準状態に対して 3 分間順応した. 順 応を待つ間に実験者が被験者に対してインストラクションを与えた。 インストラクションは次のとおりである.

「今からこの部屋の明るさ感を評価する実験を始めます. 現在の 照明は評価の基準となる基準条件です．この部屋の照明がさまざま に変化しますので, 基準条件の明るさ感を 100 として, それぞれの 条件での部屋の明るさ感を数字で評価してください.

各試行前に一旦約 1 秒ブース内の照明を消灯した. その後, 基準 条件を 10 秒間提示し，続けてテスト条件を 10 秒間提示した. 10 秒 経過したら改めて基準条件に戻し, 被験者がテスト条件時のブース 内の明るさ感評価值を口頭で実験者に伝えた，照明条件を切り替え る際には約 1 秒ブース内の照明を消灯している. なお, 要求があれ ばもう一度テスト条件を提示すると被験者には伝えていたが，実際 に 2 回提示することはなかった.
この実験での明るさ感評価はあくまで相対評価であること，各条 件を提示する際の時間的な条件を䖻-していることから, 被験者の 明るさ感評価への経時対比の影響は小さいと考えられる.

実験は 18 条件について 5 回ずつ, 計 90 回の評価で構成される. 実験前の順応を開始してからすべての評価が終了するまでの所要時 間は 1 時間〜1 時間 15 分程度であった。

被験者は研究室内部の学生 7 名で, うち 4 名は過去に心理物理実 験の被験者をした経験がある. 被験者は実験の詳細な目的について 知らされていなかった。

\section{6 仮想輝度分布法の適用}

仮想輝度分布法により各条件の明るさ感の推定值を算出した. 具 体的な計算法は次のとおりである。

まず，単位仮想輝度分布をラジオシティ法により算出した．輝度 分布算出の際の具体的な条件は表 6 のとおりである.

実測輝度分布と仮想輝度分布の例を図 3 に示す. 図 3 (a)は照明 条件 3 の被験者正面壁の実測輝度分布であり，図 $3(\mathrm{~b})$ は同条件に対 応する仮想輝度分布の被験者正面壁部分である. 図 3 (c) は実測輝度 分布と仮想輝度分布の差分を表わす. 図 3 (c)中矢印で示された部分 は, 実測輝度が仮想輝度よりも極端に高い部分であり,この部分は, 局所的な高輝度部分であると認識され, 空間全体の明るさ感には直 接は影響しないと考えられる.

最後に基準条件と 18 種類のテスト条件のそれぞれについて算出 された明るさ感指標から, 次式により明るさ感推定值を算出した.

$($ 明るさ感推定值 $)=\frac{\text { (テスト条件の明るさ感指標 })}{(\text { 基準条件の明るさ感指標 })} \times 100$

ただし, 明るさ感評価值は仮想輝度分布法による明るさ感指標と 正比例の関倸にあることを仮定している.
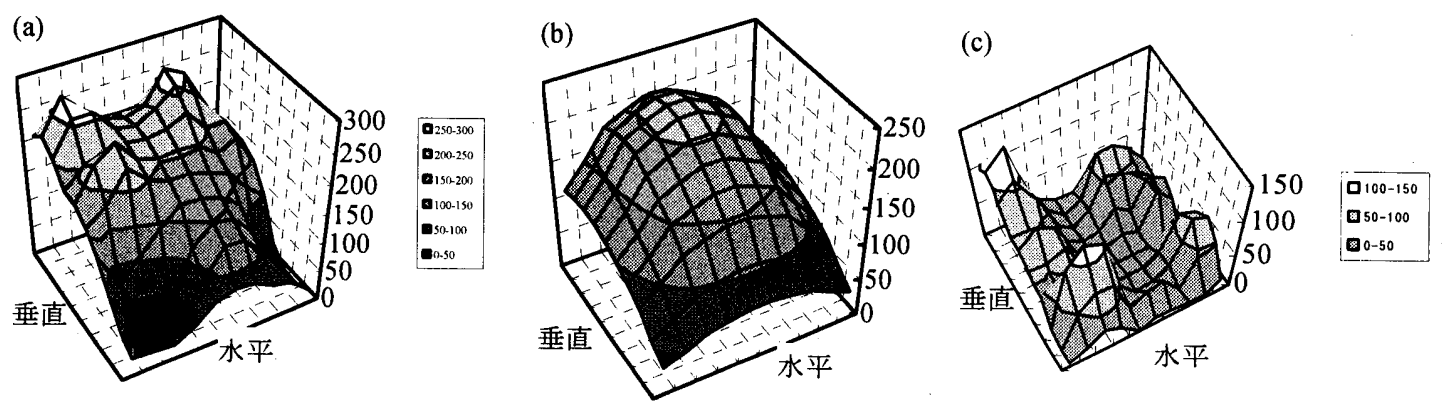

図 3 実測輝度分布と仮想輝度分布の例

（a）照明条件 3 の被験者正面壁の実測輝度分布

(b) (a)の実測輝度分布

に対応する仮想輝度分布, (c) 実測輝度分布と仮想輝度分布の差分. 


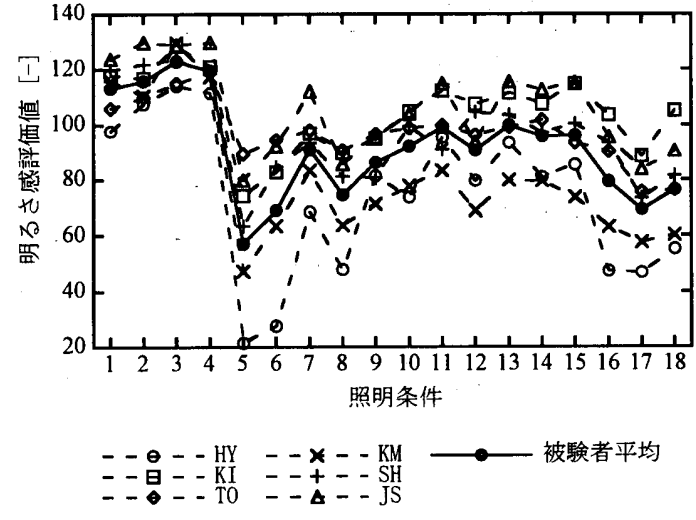

図4 実験で得られた明るさ感評価值. 各被験者の評価値と全 被験者の評価值の幾何平均を照明条件に対してプロット．

\section{7 実験結果}

明るさ感評価の結果を図 4 に示す. 図の横軸は照明条件, 縦軸は 明るさ感評価值を表わす．被験者 6 名全員について，各条件の明る さ感評価值の幾何平均をプロットしている，また，あわせて被験者 の平均もプロットしている.

各種明るさ感指標と明るさ感評価値の相関を図 5〜7に示す．図 5 はテーブル上での水平面照度, 図 6 は被験者の目の位置での鉛直 面照度, 図 7 は仮想輝度分布法による明るさ感推定值と明るさ感の 関倸を表わす，いずれの図においても，横軸は明るさ感指標，縦軸 は明るさ感評価值である，全被験者の幾何平均を条件ごとにプロッ トしている.

仮想輝度分布法による明るさ感推定値と明るさ感評価値との相 関はきわめて高く，仮想輝度分布法による空間の明るさ感推定の原 理は実大空間に詨しても適用可能であることが示された.

また, 鈶直面照度や明るさ感推定值と明るさ感評価値との相関と 比べて, 水平面照度と明るさ感評価值との相関が低いことが分かる. すなわち，水平面照度は空間の明るさ感指標としての信頼性はよく ないといえる.この結果から，明るさ感を向上させるためとして水 平面照度を高くする従来型の照明設計では，明るさ感の向上につな
がらず無䭾なエネルギーが使われる可能性があると考えられる.

\section{5. 考察}

\section{1 局部照明の明るさ感への影響}

Shepherd $ら^{9,10)}$ や小林ら ${ }^{11} に よ っ て ，$ 不均一な輝度分布は空間全 体の明るさ感に影響することが示されている，すなわち，実際の建 築照明において局部照明を導入すううことにより空間全体の明るさ感 が影響を受けることが考えられる，そこで，本実験においても局部 照明の導入による空間の明るさ感への影響について検討した。

検討の対象となったのは, 天井照明 $\mathrm{F}$ 系列(条件 1 4), 天井照明 $\mathrm{B}$ 系列(条件 5 8), 天井照明 $\mathrm{F} \& \mathrm{~B}$ 系列(条件 9 12)の 3 系列, 計 12 条件である．各照明条件系列で明るさ感評価值と，仮想輝度分布法 による明るさ感評価予測値および照度(机上面水平面照度, 被験者の 目の位置での鉛直面照度)との比較を行った。

図 8 にそれぞれの系列での明るさ感評価值の比較を示す. 横軸が 照明条件, 縦軸が明るさ感評価值である.

いずれの系列についても局部照明の導入により明るさ感評価值 は大きくなっている，また，全般照明条件で明るさ感評価の低い天 井照明 B 系列は明るさ感評価の上昇幅が大きい，逆に全般照明の条 件で明るさ感評価の高い天井照明 $\mathrm{F}$ 系列では明るさ感評価の上昇幅 が小さい.

導入した局部照明のタイプの違いに注目すると，いずれの組合せ でも天井照明とスポットライト B の併用(条件 4, 条件 8, 条件 12) がもっとも明るさ感評価值が大きく，逆に壁面ライトを併用した条 件(条件 2 , 条件 6 , 条件 10)では明るさ感評価值はそれほど大きくな っていない，天井照明と壁面ライト哭併用する条件の場合，壁面ラ イトによる壁の高輝度部分は空間全体の明るさ感に寄与しない局所 的な光として認識されていると考えられる.

天井照明 $\mathrm{B}$ 系列で最も明るさ感評価值が大きい条件 7 を天井照 明 $\mathrm{F}$ 系列と比較すると，条件 7 は天井照明 $\mathrm{F}$ 系列に属するいずれの 条件よりも評価值が小さい。このことから，実験で使われた条件に おいては全般照明による明るさ感が低い場合，局部照明の導入より も全般照明の変更の方が明るさ感向上には效果的であるといえる.

続いてそれぞれの系列において仮想輝度分布法による明るさ感 評価予測值と明るさ感評価とを重ねてプロットしたグラフを図 9 に

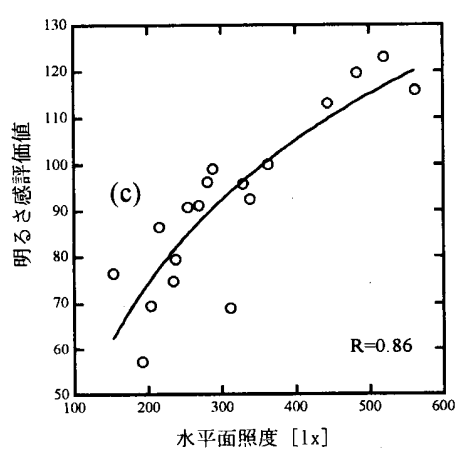

図5テーブル上の水平水平度と明 るさ感評価值との関倸. 回帰線は 対数回帰であり，相関係数は対数 回帰に対するものである。

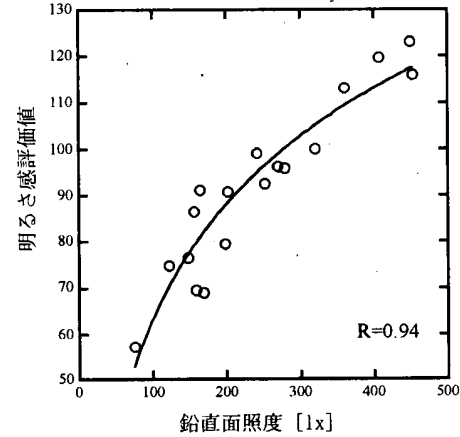

図 6 被験者の目の位置での鉛直面 照度と明るさ感評価値の関係. 回帰線などは図 5 と同じ。

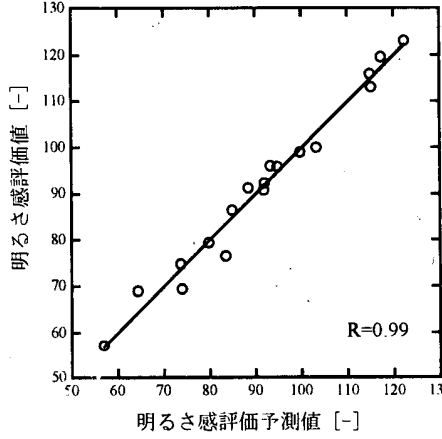

図 7 仮想輝度分布法による明るさ 感推定値と明るさ感評価值の関 係. 回帰線淔線回帰. 


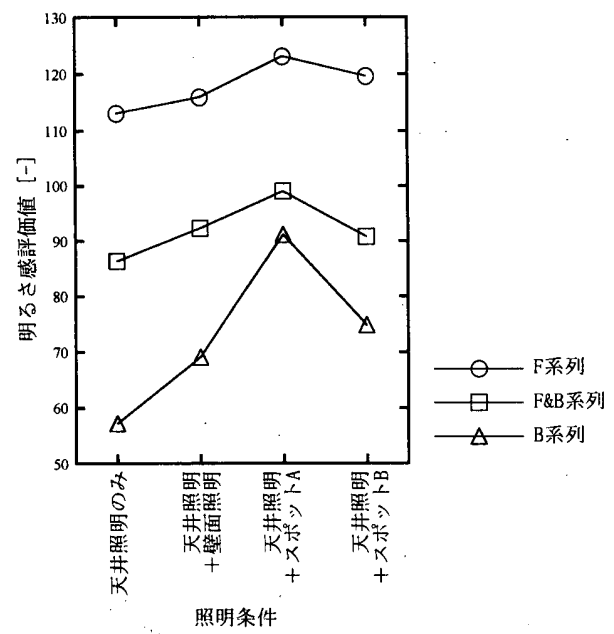

図8 各天井照明系列での明るさ感評価比較。横軸は照明条 件，綐軸は明るさ感評価值に対応する．シンボルの違いは 各天井照明系列に対応する。

示す，図 9 の横軸は局部照明の違いを表わし，縦軸は明るさ感評価 值または明るさ感評価予測值を表わす。丸，ひし形，三角形のシン ボルはそれぞれ天井照明 $\mathrm{F}$ 系列， B 系列, F\&B 系列の組合せに対応 している，黒いシンボルが予測值，白抜きのシンボルが明るさ感評 価值を表わす．また，これと比較する意味で机上面水平面照度およ び被験者の目の位置での鉛直面照度と明るさ感評価值とを重ねてプ ロットしたグラフを図 10 に示す. 図 10 の横軸が局部照明のタイプ を表わし，左側の縦軸が照度(水平面照度，鉛直面照度)，右側の繸 軸が明るさ感評価值を表わす.シンボルの違いは図 9 と同様であり， 黒いシンボルが照度，白抜きシンボルが明るさ感評価值を表わす.

天井照明と壁面ライトの併用(条件 2, 条件 6, 条件 10) と天井照 明のスポットライト B の併用(条件 3, 条件 7, 条件 11)とを比較す ると，同じ系列では水平面照度は壁面ライト併用の方が高く，鉛直 面照度は壁面ライト併用の方が高いかほぼ等しくなっている，これ に対して評価予測值はダクト型スポットライト併用の方が高くなっ ており，明るさ感評価値とよく似た傾向を示している。この結果に

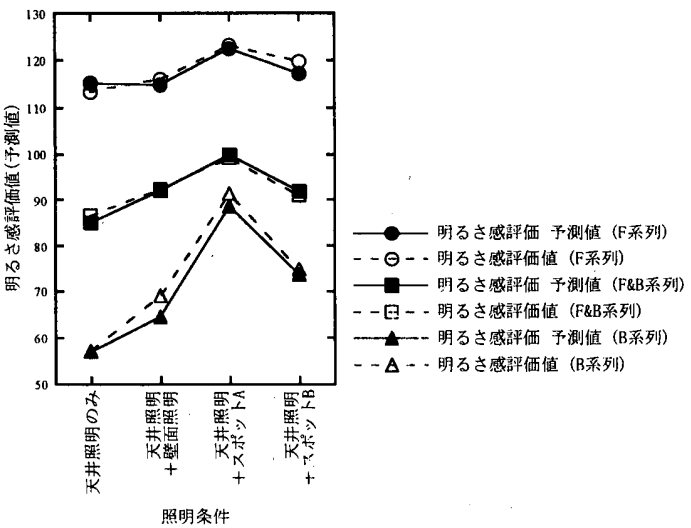

図9 各系列での仮想輝度分布法による明るさ感評価予測 值と実験で得られた明るさ感評価との比較.

横軸は照明条件，縦軸は明るさ感評価值または明るさ感 評価予測値に対応する．シンボルの違いは各系列に対応 し，黒シンボルは明るさ感評価予測值，白抜きシンボル は明るさ感評価値を表わす。

よって，局部照明を導入することによる明るさ感への影響は水平面 照度や鉛直面照度ではうまく予測できないが，また仮想輝度分布法 によってうまく予測できることが示された。

\section{2 高輝度部分の明るさ感への寄与}

ここで, 光源の高輝度部分の見えが空間の明るさ感に与える影響 について簡単に言及しておきたい. Bernecker ら ${ }^{11)}$ や Akashi ${ }^{12.13)} ら$ の研究では, 視野内の光源や高輝度部の存在が空間全体の明るさ感 を向上させるという報告がある，一方，著背らのこれまでの研究で は，空間の光量感を空間の明るさ感の決定要因であると考え，局所 的な高輝度部分は空間の明るさ感に䇃する春与が小さいものとして 処理している.これらの一見相反する研究結果の関係については今 後の検討が必要だが，整合した解沢！して次のような可能性が举げ られる．第一には，空間に配列された高輝度部分(きらめき)が空間 の光量感を高める効果を持つということである.これは現段階の仮 想輝度分布法では考慮していない効果であり，もしその効果が明る さ感に対して無視できない影響をもつとすれば，推定法の拡張が必 要となるだろう，第二には，高輝度光源 の配列が光源の強さ感を高めているとい う可能性である. Akashi らの研究でも設 定されたように，実際の建築空間の内装 は一般に高い反射率を有するので，光源 が強ければ空間を満たす光量も多くなる。 したがって, 光源の強さ感が高まれば, 空間の明るさ感も高い結果が得られるだ ろう。第三には明るさ感という言葉の意 味の捉え方の違いが考えられる．日常的 には明るいという言葉は，光源が強い状 態にも，部屋に光が満ちているような状 態にも用いられる、そして一般にはその 2 つの状態は互いに相関する関係にある ので，特に矛盾なく明るさという言葉を 使用することができる．また、きらめき 
の配列による一種の「にぎやかさ」が明るいという印象と結びつい ていることなども考えられるだろう．著者らは照明環境の心理を研 究する際には, これらの諸感覚を可能であれば区別して扱うべきで あると考えている．例えば空間の内装反射率が低い場合や照明の配 光に制限があるような状況下では，光源の強さ感と空間の光量感は 乘離する可能性がある，そのような場合に空間の明るさ感を決めて いる主要因は空間の光量感であるというのが著者らの解釈である. 高輝度部分の見えの効果に関しては今後の検討が必要である。

最後に仮想輝度分布法の有効な適用範囲について述べておく. 本 研究も含めてこれまでの実験では天井からの光が支配的な空間を想 定しており，仮想光源として天井全面の拡散光源を仮定してきた。 したがって, 現段階で有効性が確認された本方法の適用範囲は, 空 間全体の光の分布が室に対しておおよそ対称性を有する空間としな くてはならない, もちろん, 局所的な輝度の不均一性や内装反射率 構成などの条件には対応可能である. 今後は，片側採光によって側 面からの照明が支配的となり照度分布に全体的な傾斜がある空間な どについても検討を進めることが必要である。

\section{6. まとめ}

本研究で得られた結論は次のとおりである.

1. 仮想輝度分布法は実大空間の明るさ感推定に対しても適用可能 である。

2. 局部照明を導入することによる明るさ感への影響は，仮想輝度 分布法により水平面照度，鉛直面照度よりも精度よく推定する ことができる

\section{謝辞}

本研究の一部は照明学会研究助成および日本学術振興会科学研 究費によって行われた。

\section{参考文献}

1) 中村芳樹：明るさと明るさ感，照明学会誌，86-10，pp. 746-753，2002.10

2) 岩井: 明るさ感研究から生まれた新配光の住宅用天井㨁付け形照明器具, 照明学会誌, 86-10, pp. 782-786, 2002.10

3）石田，荻内：空間の明るさ感の心理的決定要因一光源の強さ感と空間の 光量感一，照学誌，84-8A, pp. 473-379, 2000.8

4）荻内，石田：仮想輝度分布法による空間の明るさ感の物理的な評価法一 均等拡散面の場合一，照明学会誌，84-8A，pp. 529-533，2000.8

5) Ogiuchi Y., Ishida T. and Hokoi Shuichi; Quantitative estimation of environmental brightness based on its perceptual composition, CIE 24th Session (Warsaw, Poland), 1-i, pp. 29-35, 1999.6

6) Ishida, T., Ogiuchi, Y.: Psychological determination of brightness of a space perceived strength of light source and amount of light in the space -. J. Light Vis. Env., 26-2, pp. 29-35, 2002

7) 石田：空間の明るさ感の評価一仮想輝度分布法, 照明学会誌, 86-10, pp $759-763,2002.10$

8) Ogiuchi Y., Ishida T.: Environmental Brightness Estimation for Full-Scale Spaces by the Virtual Luminance Distribution Method, CIE 25th Session (San Diego, US), 1, pp. D1-30 - D1-33, 2003.6

9）荻内，石田：仮想輝度分布法による空間の明るさ感推定の有効性，照明 学会誌, 87,pp. 105-112, 2003.2

10) 成定：明るさ感‥ある複雑な感じ，照明学会誌，67，pp. 297-299，1983.7

11) Bellchambers, H.: Illumination, colour rendering and visual clarity, Light. Res. Technol., 4, pp. 104-106, 1972

12) Levermore, GJ.: Perception of lighting and brightness from HID sources, Light.
Res. Technol, 26, pp. 145-150, 1994

13) Howlett GL: The coming redefinition of photometry, J. Illum. Engng. Soc., 15, pp. 5-8, 1986

14) Aston, S. and Bellchambers, H.: Illumination, colour rendering and visual clarity, Light. Res. Technol., 1, 259-261, 1969

15) 㴊田, 富永, 秋山, 河本, 森： 3 波長蛍光ランプの照明効果, 照明学会 誌, 65, pp. 526-533, 1981 .

16) 納谷，橋本：高演色性蛍光ランプの照明下での明るさ感，照明学会誌， 67 , pp. $260-265,1983$

17) 森：照明の明るさ感の数量的評価, 東芝レビュー, 40,pp. 1132-1135, 1985

18) Bernecker, Craig A. and Mier, John M.: The effect of source luminance on the perception of environment brightness, J. Illum. Engng. Soc., Fall, pp. 253-271, 1985

19) Akashi, Y., Akashi, I., Tanabe, Y., and Kanaya, S.: The sparkle effect of luminaires on the sensation of brightness, Proc. 23rd CIE, 1, pp. 176-179, 1995

20) 明石, 向, 坂上, 田辺：省エネルギーと快適性の両立を目指したオフィ ス照明システムーパーソナル\&フ:ビエント照明方式の実用化一， National Tech. Rep., 43-2, pp. 200-206, 1997

21) Loe, D. L., Mansfield, K. P. and Rowlands, E.: Appearance of lit environment and its relevance in lighting design: Experimental study, Light. Res. Technol., 26-3, pp. 119-133, 1994

22) Tiller, D. K. and Veitch, J. A.: Perceived room brightness: Pilot study on the effect of luminance distribution, Light. Res. Technol., 27-2, pp. 93-101, 1995

23) Shepherd, A. J., Julian, W. G., and Purcell A. T.: Gloom as a psychological phenomenon, Light. Res. Technol., 21-3, pp. 89-97, 1989

24) Shepherd, A. J., Julian, W. G., and Purcell A. T.: Measuring appearance: Parameters indicated from gloom studies, Light. Res. Technol., 24-4, pp. $203.214,1992$

25) 小林, 中村, 木津, 乾 : 空間の輝度分布が室内の明るさ感に与える影響, 日本建築学会計画系論文報告集, No. 487, pp 33-41, 1996.1

26) 岩井, 斎藤, 畦, 阪口: 住宅居間の明るさ感ーダウンライトを設置した 場合一, 照明学会誌, 83-2, pp. 81-86，1999.2

27) 中村；乾，沢田：輝度分布の表現法に関する研究，日本建築学会計画系 論文報告集，第 431 号，pp. 17-24，1992

28) 中村, 乾: 視環境の輝度分布特性に関寸る研究; 日本建築学会計画系論 文報告集，438，pp. 1-8，1992.8

29）中村：光環境における輝度の対比の定量的検討法, 照明学会誌, 84-8A, pp.522-528, 2000.8

30）池田，金子：照明認識視空間人の初期視覚情報の影響一明度と彩度の場 合一，照明学会誌，80-5, pp. 319-324, 1996.5

31) 池田, 本永, 松澤, 石田: 色パターンの照明認識視空間と局所照明認識 闎，光学，22-5, pp.289-298，1993.5

32) 山内, 池田, 篠田：初期視覚情報の増大による照明認識視空間の構築, 光学, $30-1, p p .41-48,2001.1$

33）溝上，池田，篠田：照明認識視空間のサイズによって影響される見えの 明度, 照明学会誌, $82-2,2001.2$

34）山口，篠田，池田：照明認識視空間の明るさサイズの測定による実環境 における空間の明るさ感の評価，照明学会誌，86-11，2002.11

35) Moore, T., Graves, H., Perry, M. J. and Carter, D. J.,: Approximate field measurement of surface luminance using a degital camera, Light. Res. Technol., $32-1$, pp. $1-11,2000.1$

(2003年 9 月 8 日原稿受理, 2004 年 5 月11日採用決定 